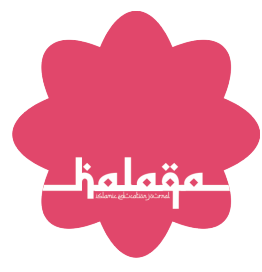

OPEN ACCESS ISSN 2503-5045 (online) ISSN 1412-9302 (print)

Edited by: Eni Fariyatul Fahyuni Reviewed by: Khozin

${ }^{*}$ Correspondence: Silwana Mumthaza silwanamumthaza@gmail.com

Received: 31 Desember 2020 Accepted: 18 Januari 2021 Published: 25 Januari 2021

Citation:

Mumthaza S, Anshori I and Istikomah I (2021) Increased patterns of Islamic social interaction with E-Learning-based learning methods during the COVID-19

Pandemic.

Halaqa: Islamic Education Journal.

\section{Increased patterns of Islamic social interaction with E-Learning-based learning methods during the COVID-19 Pandemic}

\section{Peningkatan pola interaksi sosial islami dengan metode pembelajaran berbasis E-Learning di masa Pandemi COVID-19}

\author{
Silwana Mumthaza ${ }^{1 *}$, Isa Anshori ${ }^{2}$, Istikomah Istikomah ${ }^{1}$ \\ ${ }^{1}$ Magister Manajemen Pendidikan Islam, Universitas Muhammadiyah Sidoarjo, Indonesia, ${ }^{2}$ Universitas Islam Negeri Sunan \\ Ampel Surabaya, Indonesia
}

The spread of Corona in the world in 2019-2020 caused a global pandemic. The COVID 19 pandemic is forcing changes on many fronts. This impact also affects education in a big way. Meanwhile, the school acts as a forum to form intellectualism and values that arise in individuals so that they are able to influence social changes in society continuously and massively. The goal is for individuals to be able to survive and adapt in this pandemic.Various educational innovations were made as a step to be able to survive with the interaction of the realm of education. Learning process innovation is an important strategy in school innovation. The use of ICT is carried out as an effort to improve the business of running education. Elearning is a learning model that can be applied with limited mobility. However elearning is a double-edged knife-like tool. On the one hand, this method has effectiveness that can work during a pandemic. But on the other hand there are social changes that occur as a result of e-learning. This social change changes the transition of knowledge, attitudes, beliefs, skills and other aspects. As a result, social changes in education as a process of teaching and learning will experience social shifts. The social shift that occurs is a form of change in social interaction. The sociological approach to education is used to understand the changes in interaction that arise in e-learning. Limited due to this pandemic, humans must still have to perform their function as social individuals to influence each other. Education as a forum for influence must carry out this interaction through e-learning.Social interaction is one of social activities and integration. Contact and communication will create social interaction so that they are able to carry out a role in their life. This interaction is both associative and dissociative.The identification of social interactions in e-learning learning can provide insight to the teacher in providing important strategies in more meaningful learning so that learning objectives can be achieved. Teachers can also explore the potential of e-learning as an alternative to future education.

Keywords: Elearning, COVID 19 Pandemic, Social Interaction, Sociology of Education 
Adanya persebaran Corona di dunia di tahun 2019-2020 mempengaruhi pendidikan secara besar besaran. Sedangkan sekolah berperan sebagai wadah untuk membentuk intelektualisme dan nilai yang muncul pada individu sehingga mampu mempengaruhi perubahan sosial masyarakat secara kontinu dan masif. Tujuannya agar individu mampu bertahan dan menyesuaikan di masa pandemi ini. Oleh sebab itu inovasi pendidikan dibuat sebagai langkah untuk bisa tetap bertahan dengan interaksi ranah pendidikan. Inovasi proses pembelajaran merupakan strategi penting dalam inovasi sekolah. Pemanfaatan TIK dilakukan sebagai salah satu usaha dalam meningkatkan usaha menjalankan pendidikan. Elearning merupakan model pembelajaran yang bisa diterapkan dengan keterbatasan mobilitas. Namun elearning adalah alat seperti pisau bermata dua. Di satu sisi metode ini memiliki efektivitas yang dapat berjalan di masa pandemi. Namun di sisi lain terdapat perubahan sosial yang terjadi. Perubahan sosial ini merubah transisi pengetahuan, sikap, kepercayaan, ketrampilan dan aspek aspek lain. Akibatnya perubahan sosial dalam pendidikan sebagai proses mengajar dan belajar akan mengalami pergeseran sosial.

Kata Kunci: Elearning, Pandemi COVID 19, Interaksi Sosial, Sosiologi Pendidikan. 


\section{PENDAHULUAN}

Persebaran virus Corona di dunia di tahun 2019-2020 menyebabkan pandemi global. Persebaran terjadi karena transmisi manusia ke manusia menyebabkan sejumlah besar infeksi masyarakat. Masyarakat yang terinfeksi akan mengalami gejala gejala gangguan pernafasan dan demam. Kapabilitas Coronavirus dalam menginfeksi individu mampu berakhir pada rasio kematian yang tinggi dalam waktu singkat. Selain itu tingkat okupansi sarana medis yang belum mencukupi dengan laju infeksi yang tinggi menyebabkan permasalahan baru dalam bidang medis. Beberapa poin ini yang menyebabkan WHO menetapkan Coronavirus menjadi pandemi dunia pada 1-12 Januari 2020 WHO and Johnson (2020). WHO mencatat hingga November 2020 angka 53.164.803 kasus terkonfirmasi positif, 1.300 .576 kasus kematian, dengan 220 negara dengan area dan daerah dengan kasus terkonfirmasi Organization (2020). Selain itu WHO juga memberikan laporan mingguan yang bisa di tinjau oleh masyarakat umum. Aksebilitas ini bertujuan untuk mengetahui perkembangan pandemi yang terjadi secara global WHO and Johnson (2020). Usaha ini dilakukan untuk memberikan informasi dan mengedukasi masyarakat dunia terkait informasi epidemiologikal, data dan tren perkembangan kasus COVID 19.

Pandemi Corona Ini memaksa perubahan dalam berbagai bidang. Di berbagai negara terjadi penurunan kesehatan, ekonomi, sosial dan pendidikan secara signifikan. Pemasaran global, stok pangan, tingkat okupansi perjalanan, investasi merupakan bidang bidang yang mengalami penurunan besar besaran. Hal ini karena adanya pembatasan interaksi antar manusia yang diterapkan sebagai bagian kebijakan negara negara yang mengalami pandemi ini Abodunrin et al. (2020). Pemerintahan di banyak negara harus mengambil langkah keras untuk melaksanakan pembatasan dan regulasi perjalanan untuk menekan angka dan penyebaran virus.Indonesia sebagai salah satu negara terdampak pandemi ini juga mengalami peningkatan imbas efek negatif. Imbas ini juga mempengaruhi pendidikan Islam secara besar besaran. Oleh sebab itu pihak pihak terkait harus mengambil langkah strategis untuk menghadapi masalah ini Wajdi et al. (2020). Terdapat beberapa langkah yang dapat dilakukan. Pertama, memberikan informasi pada siswa dan praktisi pendidikan Islam terkait pandemi ini. Hal ini dapat dilakukan dengan sosialisasi yang intensif dari dinas Kesehatan. Kedua, melakukan usaha untuk mengurangi mobilisasi masyarakat pendidikan.

Pemerintah juga melakukan beberapa kebijakan sebagai usaha penyesuaian diri dengan kondisi pandemi. Manajemen dan mobilisasi masyarakat pendidikan harus di tekan untuk mengurangi penyebaran virus. Perubahan ini termaktub pada Surat Edaran Menteri Pendidikan No 4 Tahun 2020 tentang pelaksanaan kebijakan pendidikan pada masa darurat Pandemi COVID. Pertimbangan utama adalah kesehatan lahir dan batin warga sekolah dalam pelaksanaan pendidikan dan Kebudayaan (Kemendikbud). Pada dasarnya Lembaga Pendidikan Islam memiliki peran dalam pembentukan siswa selama mengenyam pendidikan di lembaga tersebut Lahmi (2016). Peran ini membantu generasi muda agar bersiap dalam menghadapi tantangan yang telah disediakan oleh dunia. Lembaga pendidikan Islam juga memberikan peran, tujuan dan sasaran penting dalam pelaksanaan pendidikan di Indonesia.

Peranan sekolah sebagai wadah untuk membentuk intelektualisme dan nilai yang muncul pada individu sehingga mampu mempengaruhi perubahan sosial masyarakat secara kontinu dan masif. Peranan ini berdasarkan nilai atau akhlak dalam konteks intelektualitas maupun internalisasi nilai yang dikembangkan di masyarakat Lahmi (2016). Nilai yang di kembangkan di sekolah merupakan nilai yang berkembang di masyarakat. Nilai atau perilaku ini akan menggali ranah intelektualitas individu. Siswa akan mencari tahu mengapa nilai tersebut berkembang di masyarakat, sehingga siswa akan memahami, melaksanakan dan menerapkan nilai tersebut secara penuh dan sadar. Proses inilah yang menjadi ruang lingkup dan keunggulan sekolah. Selain itu Lembaga Pendidikan Islam memberikan nilai positif yaitu adanya hubungan antara nilai ragawi, rohani dan pemikiran Islam. Nilai filosofis ini memberikan keunggulan intelektualitas masyarakat.

Sekolah memberikan lingkungan pendidikan sekunder. Dalam hal ini seseorang akan menghabiskan sebagian besar waktunya untuk menggali ilmu di sekolah. Intensitas dan frekwensi kehadiran individu yang tinggi ini menyebabkan sekolah mampu mempengaruhi pembentukan jiwa manusia Sarwono (2011). Lembaga Pendidikan Islam memiliki pendidikan yang dapat diterapkan sebagian besar waktu dan mampu mempengaruhi jiwa siswa menjadi lebih religius dan mampu menggali nilai nilai keislaman pada ilmu yang didapat.

Sasaran pendidikan yang terarah untuk pengembangan kekuatan fisik, intelektual dan moral yang akan dilaksanakan di lingkungan tempat tinggalnya. Sekolah menjadi bagian untuk menjaga keberlangsungan di komunitas manusia Maliki (2010). Sasaran ini harus bisa dicapai sebuah lembaga pendidikan pada setiap masa. Lembaga Pendidikan Islam tentunya memiliki sasaran dalam mengembangkan nilai religius pada peserta didik. Lembaga pendidikan Islam sebagai salah satu wadah pendidikan juga memberikan penguatan tentang kebutuhan manusia yang bersifat holistik. Wadah ini mendorong manusia untuk sadar terhadap tanggung jawab sebagai makhluk ciptaan Tuhan dan sebagai individu sosial agar menjadi individu yang mampu mewujudkan khalifatul fil Ardhi Syafe'i (2016).

Kondisi pandemi mendorong adanya penyesuaian pada lembaga yang menangani sektor pendidikan. Penyesuaian yang terjadi pada sektor pendidikan dilakukan sebagai bentuk adaptasi. Berbagai inovasi pendidikan dibuat sebagai langkah untuk bisa tetap bertahan dengan interaksi ranah pendidikan. Beberapa inovasi yang harus ditempuh misalnya dalam bidang kurikulum yang mengalami perubahan dan penyesuaian. Selain itu penyesuaian kurikulum ini memberikan imbas guru harus lebih inovatif dan kreatif. Sekolah sebagai lembaga juga memberikan kebijakan dan fasilitas kepada guru agar mampu berinovasi Sudrajat et al. (2020). 
Hal ini akan memberikan imbas pada Sekolah Islam untuk mengadakan penyesuaian. Hal ini bertujuan agar Inovasi pendidikan yang dilakukan terdiri dari beberapa aspek yaitu inovasi kurikulum, inovasi komponen tujuan, inovasi isi/materi pembelajaran, inovasi proses pembelajaran dan inovasi evaluasi Sudrajat et al. (2020). Inovasi ini memiliki tujuan agar lembaga pendidikan Islam tetap memberikan peran penting dalam masyarakat yaitu agar peserta didik mampu bertahan dalam tantangan zaman. Dalam hal ini Lembaga Pendidikan Islam ditantang untuk mampu bertahan dalam kondisi medis Pandemi Covid.

Salah satu strategi penting adalah pada inovasi proses pembelajaran Sudrajat et al. (2020). Hal ini bertujuan agar bahan ajar bisa tersampaikan pada peserta didik secara efektif dan efisen. Proses pembelajaran dilaksanakan dengan memanfaatkan teknologi audio dan video atau kombinasi keduanya. Selain itu skenario pembelajaran harus dipersiapkan dengan baik dengan merancang pembelajaran berbasis internet. Beberapa strategi yang diterapkan adalah pemanfaatan media berbasis teks (misalnya web, google classroom, Whatsapp), media berbasis suara dan teks (Whatsapp), media panduan audio dan video (Zoom, googlemeet), media perpaduan teks, sharing file, audio dan video (aplikasi Lark). Namun seiring dengan perubahan pola pendidikan daring (dalam jaringan) dan selama masa di rumah, maka proses belajar dilakukan dari rumah, akibatnya kondisi fisik sekolah Islam sebagai education center harus memiliki arah baru. Durkeim menyatakan bahwa lembaga pendidikan berperan untuk menjaga nilai nilai moral dan menjadi dasar bagi pertumbuhan masyarakat Anshori (2004). Fungsi pendidikan ini juga harus dilaksanakan dari rumah. Tantangan ini harus dijawab oleh Lembaga Pendidikan Islam agar transfer nilai (transfer of Values) dapat terus terlaksana dengan segala keterbatasannya.

Proses belajar harus terus berjalan. Permasalahan ini dapat diatasi dengan alternatif pemanfaatan teknologi yang terdiri dari informasi dan komunikasi. Pemanfaatan TIK di bidang pendidikan sebagai salah satu usaha dalammeningkatkan kualitas pendidikan. Informasi yang didapat di komputer dan terkoneksi dengan jaringan internet dapat berkontribusi besar dalam penyebaran informasi dan jaringan. Teknologi ini memberikan perubahan terhadap peran guru Muhtadi (2006). Elearning merupakan model pembelajaran yang bisa diterapkan dengan keterbatasan mobilitas. Model pembelajaran ini mendorong efektivitas dan fleksibilitas pendidikan Nurdiansyah and Fahyuni (2016). Semua pembelajaran dengan pemanfaatan internet dan proses pembelajaran terbentuk maka dikategorikan sebagai pembelajaran berbasis web atau elearning (electronic learning). Maka terdapat dua kategori untuk melengkapi pembelajaran elearning, yang pertama adalah sumber data, baik gratis maupun berbayar. Dan kedua, adalah proses implementasi pembelajaran elearning.

Pembelajaran berbasis internet atau elearning dapat memfasilitasi siswa melakukan Nurdiansyah and Fahyuni (2016) 1). Discovery (menemukan) hal hal yang baru, meliputi browsing dan pencarian informasi tertentu yang berkaitan dan berhubungan dengan materi yang diingini, 2). Communication (komunikasi) jaringan internet memberikan informasi secara cepat, murah dan kompleks antar dan inter lembaga, 3) Collaboration, (kolaborasi) menggabungkan beberapa informasi yang berkaitan dengan informasi lainnya yang diinginkan oleh pengguna. Namun disamping mendapatkan keuntungan dan kelebihan, pada pembelajaran elearning terjadi perubahan sosial. Hal ini seperti pisau dengan dua bilah. Di bilah satu, metode ini memiliki efektivitas yang dapat berjalan di masa pandemi. Namun di bilah lain terdapat perubahan sosial yang terjadi akibat pembelajaran elearning. Perubahan sosial ini merubah transisi pengetahuan, sikap, kepercayaan, ketrampilan dan aspek aspek lain. Akibatnya perubahan sosial dalam pendidikan sebagai proses mengajar dan belajar akan mengalami pergeseran sosial Zainuddin (2008).

Pergeseran sosial yang terjadi merupakan bentuk perubahan interaksi sosial. Interaksi sosial di ranah pendidikan dapat dimengerti dengan menggunakan pendekatan ilmu sosiologi pendidikan. Oleh sebab itu maka dibutuhkan pendekatan sosiologi pendidikan untuk memahami perubahan interaksi yang muncul dalam pembelajaran elearning. Sosiologi pendidikan sebagai ilmu mempelajari erubahan sosial yang terjadi akan berpengaruh pada sistem sosial (social system), nilai-nilai yang ada, sikap serta pola perilaku yang berjalan pada lembaga lembaga kemasyarakatan sebagai himpunan pokok manusia. Perubahan ini terjadi dipengaruhi oleh kondisi dan struktur masyarakat.

Interaksi sosial yang terjadi pada pembelajaran elearning memiliki ciri khas yang menarik untuk dikaji. Hal ini terjadi karena manusia sebagai individu sosial harus saling mempengaruhi. Namun karena keterbatasan akibat pandemi ini, maka manusia tetap harus melakukan fungsinya. Pendidikan sebagai wadah untuk memberikan pengaruh harus melakukan interaksi ini melalui elearning. Interaksi sosial terjadi karena interaksi guru dengan siswa, siswa dengan siswa dan siswa dengan lingkungan. Tujuan penelitian ini adalah untuk mengidentifikasi interaksi sosial islami yang terjalin pada pembelajaran elearning. Dengan identifikasi interaksi sosial islamiini maka diharapkan dapat memberikan pandangan kepada guru dalam memberikan strategi penting dalam pembelajaran bermakna (meaningful). Nantinyatujuan pembelajaran yang bermakna diharapkan akan tercapai dengan baik. Guru juga dapat menggali potensi elearning sebagai alternatif pendidikan masa depan. Selain itu Lembaga Pendidikan Islam dapat terus melaksanakan transfer nilai islami (transfer of values) dengan kondisi yang baru sebagai bentuk adaptasi.

\section{METODE}

Penelitian ini merupakan penelitian kualitatif dengan teknik analisis deskriptif. Penelitian ini melakukan kajian kepustakaan (library research) dengan mengamati, dan memberikan gambaran terhadap fenomena yang ada, dan sedang berlangsung saat ini maupun saat yang lampau. Penelitian ini meng- 
gunakan metode pengumpulan data kualitatif, yaitu prosedur penelitian yang menghasilkan data deskriptif berupa informasi secara langsung, mendalam, tidak terstruktur. Data deskriptif yang diambil berupa kalimat tertulis maupun lisan dari sumber atau perilaku pengamatan. Penelitian ini mengambil sumber primer dan sekunder. Sumber data primer merupakan sumber data utama yang langsung memberikan data pada pengumpul data Sugiyono (2017). Sumber data primer didapat dari informasi berupa artikel yang berhubungan dengan pembahasan. Data sekunder didapat dari data yang sudah ada dan terdahulu dan mempunyai hubungan masalah yang diteliti meliputi literatur yang ada. Data sekunder merupakan sumber data yang diambil pengumpul data secara tidak langsung, misalnya melalui dokumen atau pihak ketiga Sugiyono (2017). Data yang didapat berupa diskusi grup terfokus dan pendapat para ahli. Data sekunder juga dapat berupa artikel yang mendukung penelitian ini dan sudah dipublikasikan kepada masyarakat Sugiyono (2017).

Teknik pengumpulan data meliputi observasi, dokumentasi, dan triangulasi (gabungan). Observasi merupakan pengamatan yang dilakukan selama kegiatan penelitian. Dokumen merupakan catatan peristiwa yang sudah terjadi dalam bentuk tulisan, gambar atau karya. Studi dokumen melengkapi data observasi dan wawancara yang telah dilakukan. Triangulasi merupakan teknik penggabungan beberapa sumber data yang telah dikumpulkan sebagai bahan pengujian kredibilitas data Sugiyono (2017). Analisis data menggunakan Model Miles dan Huberman Sugiyono (2017) dimana terdiri dari beberapa aktivitas yaitu (1) pengumpulan data / Data collection yaitu proses pengumpulan data primer dan sekunder di lapangan, (2) Reduksi data / Data reduction yaitu memilih dan memilah data yang berhubungan dengan nilai temuan (3) Penyajian data / Data Display yaitu mengorganisasikan data menjadi pola hubungan, Conclusing Drawing / Verification yaitu penarikan kesimpulan.

Uji validitas data yang diambil pada penelitian ini menggunakan teknik triangulasi yaitu proses pengujian data dari berbagai sumber, dengan berbagai cara dan berbagai waktu. Triangulasi yang dilakukan ada 3 tahap yaitu (1) triangulasi sumber data (2) triangulasi teknik pengumpulan data dan (3) triangulasi waktu pengumpulan data. Artikel ini berfokus pada Pandemi COVID 19, Pembelajaran Elearning yang dilaksanakan, dan interaksi sosial Islami yang terjadi pada masa tersebut.

\section{HASIL DAN PEMBAHASAN}

\section{Hasil Penelitian}

\section{Pandemi Covid 19}

Coronavirus merupakan kelompok varietas yang menyebabkan adanya gangguan demam dan infeksi respirasi saluran atas. Coronavirus merupakan virus umum yang mengalami mutasi dan menyebabkan infeksi pernafasan pada manusia dan menyebar antar manusia. Penelitian ditengarai ditemukan sebagai awal mula mutasi gen dan penyebaran pertama kali di daerah Wuhan, China Wimalawansa (2020). World Health Organization memberikan sebutan untuk genera baru virus ini 2019 novel coronavirus (COVID-19) pada bulan Januari 2020. Kemudian selanjutnya penetapan nama COVID 19 diumumkan pada bulan Februari. COVID 19 merupakan tipe virus dengan struktur genom coronavirus dan secara genetik terkait dengan Severe Acute Respiratory Syndrome(SARS) dan Middle East Respiratory Syndrome(MERS). Virus ini merupakan kluster beta-coronavirus dan sejenis dengan SARS-like pada kelelawar (SL)-ZC45, SL-ZXC21, SARS-CoV dan MERSCoV Lai et al. (2020). Kesamaan struktur genetika ini menyebabkan variasi pembawa virus (host). Selain itu spektrum jenis hewan vertebrata sebagai inang, misalnya jenis burung, mamalia, babi, kelelawar. Strain virus mampu menyebabkan kematian dengan variasi kelainan antara lain kelainan pernafasan saluran atas dan bawah, tumor abdominal, kelainan liver kronis, miocarditis, kelainan kardiovaskular dan disfungsi ginjal.

COVID 19 merupakan jenis coronavirus yang menyebabkan adanya gangguan pneumonia yang tidak biasa. Individu dengan infeksi ini akan mengalami penurunan sistem imun. Gejala individu antara lain adalah sejumlah gangguan, pneumonia dan kematian. Masa inkubasi COVID 19 terjadi antar 2-6 hari. Individu dengan infeksi akan terjadi pada 4 hingga 14 hari. Walaupun belum muncul gejala pada tubuh, inang (host yaitu manusia) akan berpotensi menyebarkan virus selama waktu tersebut melalui droplet (percikan cairan) yang terbawa penderita. Apabila penderita melakukan mobilitas, maka droplets akan tersebar secara luas. Potensi penyebaran ini akan memperluas daya infeksi virus Wimalawansa (2020). Karena ketidakpastian dan kurangnya manivestasi yang jelas maka terdapat ukuran standar yaitu 14 hari karantina untuk mencegah penyebaran lebih luas. Sekuens gen ini sejenis dengan SARS dan MERS yang sebelumnya pernah menjadi epidemi wilayah. Berdasarkan data, prediksi rasio fatalitas akibat COVID 19 terjadi di angka 10 sampai dengan 30\%. Namun resiko yang tercatat adalah 2-5\%. WHO mengestimasikan 3$4 \%$ resiko yang muncul. Namun pandemi ini memiliki peningkatan potensi lebih tinggi jika tanpa ada usaha untuk menekannya Mahase (2020).

Penyebaran virus COVID 19 melalui udara, sentuhan dan kontak fisik individu. Oleh sebab itu paparan orang yang terinfeksi terutama di tempat umum, transportasi umum, dan alat umum serta sebaran udara merupakan media penyebaran virus ini. Virus ini dapat bertahan pada droplet yang dihasilkan oleh penderita melalui batuk, bersin, bicara dan pernafasan Wimalawansa (2020). Karena droplet lebih berat dari ukuran virus maka droplet dapat terpancar maksimal 6 kaki dari individu. Penggunaan masker respiratorwajah merupakan alat yang dapat menekan laju droplet. Masker respirator-wajah yang sesuai dapat menjadi usaha untuk individu terinfeksi maupun belum terinfeksi. Prinsip prinsip dalam infeksi penyakit ini dapat digunakan pihak 
pihak terkait dalam penyusunan kebijakan yang ada dalam masyarakat Wimalawansa (2020). Misalnya menjauhi tempat tempat ramai, penyediaan tempat cuci tangan dengan sabun dan air, penggunaan hand sanitizer standar medis, dan menutup hidung dan mulut dengan tisu usap sekali guna ketika batuk ataupun bersin. Usaha untuk mengurangi sentuhan pada area mata, hidung dan mulut, mencuci tangan terlebih dahulu sebelum menyentuh area tersebut, tetap di rumah ketika flu atau batuk maupun gangguan pernafasan dilakukan untuk meminimalisir resiko penyebaran virus. Penggunaan terapi medis seperti asupan vitamin $\mathrm{D}$ dan antioksidan, mikronutrien zinc, selenium diberikan untuk menjaga imun tubuh tetap bekerja maksimal.

Peneliti medis dunia juga melakukan upaya mencari kajian untuk mengamati data primer terkait jenis virus ini Currie et al. (2020). Hal ini dilakukan agar peneliti medis dapat mendapatkan gambaran utuh tentang virus ini. Sehingga dapat memberikan saran terbaik di bidang medis. Selain itu terdapat beberapa kebijakan untuk membatasi penyebaran COVID-19. Prinsip umumnya adalah dengan membatasi mobilitas individu. Beberapa wilayah menerapkan skrining di perbatasan dan jalur penerbangan. Selain itu terdapat wilayah karantina yang membatasi daerah daerah dengan resiko tinggi. Pekerja kesehatan harus lebih peka untuk identifikasi kasus yang mungkin terjadi, isolasi pasien secepatnya dan mencari saran terbaik dari petugas medis lain (misalnya dokter dan spesialis patologi) Mahase (2020). Terdapat berbagai usaha usaha yang dilakukan misalnya mengurangi pertemuan fisik dan mengganti dengan pertemuan virtual atau video.

\section{Kebijakan Indonesia Untuk Menekan Interaksi Langsung Manusia}

WHO mencatat hingga November 2020 angka 53.164.803 kasus terkonfirmasi positif, 1.300 .576 kasus kematian, dengan 220 negara dengan area dan daerah dengan kasus terkonfirmasi Organization (2020). Indonesia sebagai negara yang terdampak Pandemi COVID 19 juga mengalami krisis akibat pandemi ini. Negara ini harus memiliki kebijakan terkait proses pembelajaran. Sesuai dengan Surat Edaran Menteri Pendidikan dan Kebudayaan No 42020 dan Kebudayaan (Kemendikbud) terkait dengan pendidikan pada saat Pandemi COVID maka terdapat penyesuaian yang harus dilakukan. Penyesuaian yang harus dilakukan terkait dengan 1) Ujian Nasional (UN), 2) Belajar dari Rumah, 3) Kriteria kelulusan, 4) Kenaikan kelas, 5) Penerimaan Peserta Didik Baru (PPDB), 6 ) Dana Bantuan Operasional Sekolah.

Kementerian juga merumuskan skenario yang mendorong implementasi pembelajaran jarak jauh. "Portal Rumah Belajar", kebijakan "Merdeka Belajar", situs learning.kemdikbud.go.id sebagai pengejawantahan usaha usaha tersebut. Kementerian menggandeng platform online Smart Classes, Quipper, Google Indonesia, Sekolahmu, Zenius, Microsoft yang dapat diakses siswa dan guru untuk meningkatkan sumber belajar Abidah et al. (2020). Pemer- intahan Indonesia melalui Kementrian Pendidikan Dan Kebudayaan telah menunjukkan usaha terbaik dan maksimal dalam penanggulangan COVID. Penentu kebijakan negara telah melakukan aksi nyata untuk melindungi warga negara. Oleh sebab itu maka kewajiban warga negara untuk mendukung usaha pemerintah dengan persatuan, kolaborasi dan sinergi Wajdi et al. (2020).

\section{Dampak COVID 19 Di Bidang Pendidikan Islam}

Lembaga Pendidikan Islam merupakan struktur organisasi masyarakat yang terimbas dengan pandemi COVID 19. Oleh sebab itu lembaga pendidikan sebagai pusat pendidikan dan pembelajaran harus mengikuti perkemba gan teknologi dan mendorong percepatan dan kemudahan akses informasi dan data pada berbagai aspek kehidupan Triandoyo and Anshori (2020). Lembaga Pendidikan Islam sebagai pusat pendidikan dan pembelajaran spiritual terpaksa harus mampu beradaptasi dengan kondisi pandemi ini. Oleh sebab itu lembaga ini harus mengidentikfikasi, mengumpulkan data dan informasi sekolah yang diperlukan agar proses pendidikan dan pembelajaran berlangsung secara cepat, akurat dan lancar. Isa Anshori menyatakan bahwa guru berperan dalam pendidikan kepada siswa agar mampu mengasah fungsi akal dan budi sehingga dapat menyelesaikan tantangan dan tuntutan kehidupan dan sosial. Oleh sebab itu guru juga harus menguasai perkembangan ilmu pengetahuan dan teknologi supaya memaksimalkan potensi anak didik kelak. Individu yang telah mendapatkan pendidikan akan memiliki karakter yang sesuai dengan norma masyarakat dan norma agama sejalan dengan corak kepribadian anak didik Anshori (1993). Terlebih lagi bahwa guru di sekolah Islam juga berperan dalam asah nilai religiusitas yang harus dilakukan lewat pembiasaan.

Terdapat dasar utama tujuan nilai pendidikan islam menurut Jalaludin yang dikutip oleh Syafe'i Syafe'i (2016) yang terimplementasi dalam proses pembelajarannya, yaitu nilai hakekat penciptaan manusia, nilai tauhid dan keesaan Allah SWT, dasar moral dan fitrah islami, nilai perbedaan individu sebagai sunnatullah, dasar profesionalitas dan ketrampilan, dan dasar ruang waktu yang harus direspon sesuai tuntutan zaman. Nilai nilai pendidikan islam ini terintegrasi dalam proses pembelajaran. Namun pandemi dan kebijakan Indonesia untuk membatasi mobilitas penduduk ini menyebabkan Lembaga Pendidikan ini harus melakukan berbagai inovasi dan langkah cepat dalam situasi yang telah ada. Situasi pandemi ini cepat sekali berjalan. Dalam waktu yang terbatas, seluruh elemen Lembaga Pendidikan Islam harus merubah kebijakan dan aturan. Elemen yang terimbas adalah bidang Kurikulum, Bidang Sarana Prasarana, Bidang Kesiswaan, Bidang Humas dan Bidang Keislaman.

Berbagai inovasi yang harus ditempuh misalnya dalam bidang kurikulum yang mengalami perubahan dan penyesuaian. Selain itu penyesuaian kurikulum ini memberikan imbas guru harus lebih inovatif dan kreatif. Sekolah sebagai lembaga juga memberikan kebijakan dan fasilitas kepada guru 
agar mampu berinovasi Sudrajat et al. (2020). Lembaga Pendidikan Islam harus mendorong guru untuk menyesuaikan pembelajaran secara cepat dan bersama sama karena perubahan akibat Pandemi ini berlangsung secara cepat. Inovasi pendidikan yang dilakukan terdiri dari beberapa aspek yaitu inovasi kurikulum, inovasi komponen tujuan, inovasi isi/materi pembelajaran, inovasi proses pembelajaran dan inovasi evaluasi Sudrajat et al. (2020). Inovasi ini memiliki tujuan agar lembaga pendidikan tetap memberikan peran penting dalam masyarakat yaitu agar peserta didik mampu bertahan dalam tantangan zaman.

Langkah awal inovasi yang harus disesuaikan adalah kurikulum. Komponen kurikulum yang disesuaikan adalah tujuan, isi/ materi, proses dan penilaian pembelajaran. Komponen tujuan kurikulum disesuaikan dengan situasi dan kondisi yang berkembang di masyarakat. Isi kurikulum harus meaningful (bermakna). Penyesuaian ini bertujuan agar siswa dapat mengaplikasikan cara beradaptasi yang tepat pada lingkungan yang sedang mengalami perubahan yang besar, di era pandemi ini. Setelah Inovasi kurikulum diidentifikasi maka maka tahap selanjutnya adalah indentifikasi materi/bahan kurikulum. Materi yang disampaikan harus relevan agar bisa mencapai tujuan kurikulum. Penentuan materi dapat dihubungkan dengan situasi terkini yang terjadi, yaitu di era pandemi. Setelah itu maka proses pembelajaran akan dilakukan. Proses pembelajaran yang diberikan kepada siswa harus membutuhkan strategi penyampaian tujuan dan bahan ajar agar efektif dan efisien. Di masa ini pembelajaran hanya bisa dilakukan dengan jarak jauh. Maka teknologi pengiriman pesan berupa teks, video maupun audio dipersiapkan secara matang Nurkolis and Muhdi (2020). Proses pembelajaran harus dirancang berbasis internet. Penerapan pembelajaran ini perlu dilengkapi dengan skenario pembelajaran dengan keterlibatan peserta didik secara konstruktif dan aktif. Beberapa media yang dapat digunakan adalah media berbasis teks, media suara dan teks, media video dan teks dan beberapa aplikasi.

Setelah proses pembelajaran dilaksanakan dengan strategi yang sudah dipilih, maka evaluasi sebagai usaha pengukuran dalam pencapaian hasil pekerjaan. Evaluasi dilaksanakan untuk menentukan manfaat, nilai hasil dan memudahkan tindak lanjut keberhasilan program yang akan datang. Guru berperan sebagai aktor pembelajaran secara virtual, sehingga evaluasi berjalan secara obyektif. Umpan balik yang diterima oleh siswa sangat penting dilaksanakan sebagai instrumen perbaikan dalam pelaksanaan kurikulum. Hasil evaluasi yang didapat menjadi data untuk mengevaluasi kegiatan awal yaitu perbaikan kurikulum.

\section{Pembelajaran E-Learning}

Teknologi informasi dan komunikasi merupakan teknologi yang mengkombinasikan komputer dengan jalur komunikasi serta terjadi pertukaran data, suara dan video. Istilah ini menunjukkkan terdapat dua unsur yang menyusun teknologi yaitu gawai semisal komputer dan interaksi dalam bentuk komunikasi. Teknologi komputer merupakan teknologi operasionalisasi komputer atau perangkat lainnya yang berhubungan dengan dengan komputer. Teknologi komunikasi berkaitan dengan perangkat komunikasi jarak jauh dan mengirimkan sinyal suara maupun gambar, dalam hal ini misalnya telepon, televisi sesuai dengan pendapat William \& Sawyer dalam Muhtadi Muhtadi (2006). Nina W Syam juga memperkuat dasar Teknologi informasi merupakan ilmu agar dapat menampung informasi Muhtadi (2006). Penggunaan informasi ini dapat diakses dengan lebih mudah dan secara akurat. Ilmu ini berisi teknik dan prosedur dalam olah-simpan informasi sehingga efisien dan akurat. Informasi merupakan data yang diolahsimpan sebagai informasi yang berbentuk tulisan, suara, gambar akan mudah dicari dan dipergunakan.

Teknologi informasi merupakan cabang ilmu pengelolaan informasi, sedemikian penting sehingga mudah dicari, ditemukan dan dipergunakan. Dalam pengelolaan informasi secara cepat, efektif dan efisien maka teknologi kompuer sebagai sumber pengelolaan informasi dan penerima-penyampai informasi jarak jauh Muhtadi (2006) Di dunia pendidikan, teknologi informasi dan komunikasi merupakan instrumen dan sarana menyebarkan program pembelajaran secara searah maupun interaktif. Bagi Indonesia, hal ini sangat bermanfaat, karena kondisi geografis Indonesia secara umum terdiri dari pegunungan, kepulauan dan lingkungan yang jauh jangkauan. Penggunaan teknologi informasi dan komunikasi ini memungkinkan adayan pendidikan jarak jauh. Hal ini akan meningkatkan pemerataan informasi pendidikan di wilayah Indonesia. Arti penting ini akan meningkatkan efektifitas penyelenggaraan pendidikan di Indonesia Muhtadi (2006).

Dalam pemanfaatan teknologi informasi yang bertujuan peningkatan kualitas dan efektivitas proses pendidikan terdiri atas managemen sistem informasi (SIM), e-learning, media pembelajaran dan pendidikan life-skill Albab (2020). Beberapa usaha yang perlu dilakukan adalah 1). mengkontruksikan aplikasi database, 2). kontruksi aplikasi pembelajaran berbasis portal, web, multimedia interaktif (dalam hal ini tutorial dan learning tool), 3). Optimalisasi penggunaan TV eduksi sebagai materi pengayaan, 4). penerapan sistem informasi secara bertahap Hartanto and Purbo (2002).

E-learning sebagai bentuk teknologi informasi yang telah diimplementasikan di bidang pendidikan dalam bentuk maya dan tidak terbatas ruang dan waktu. Proses pembelajaran akan dilakukan di mana saja dan kapan saja sehingga pembelajar dapat mengembangkan kreatifitas secara mandiri Hartanto and Purbo (2002). Peserta didik dapat melakukan analisis, penggalian informasi, pengolahan data, mengeksplorasi, dan pendayagunaan informasi sehingga dapat menghasilkan tu lisan, informasi, sumber data dan pengetahuan dan menjadi pemahaman. Elearning membutuhkan jaringan internet. Hal ini menjadikan sumber belajar bukan hanya pada guru, namun siapa saja yang memberikan informasi. Pelaksanaan elearning ini dapat dilakukan oleh berbagai pihak. Secara sederhana guru dapat melaksanakan kegiatan elearning dengan mem- 
buat situs pembelajaran (learning sites) atau situs sekolah yang dihubungkan (link) dengan situs yang berkaitan dengan pembelajarannya. Situs tersebut dapat diisi dengan materi pelajaran yang mewakili dan evaluasi yang komprehensif dan integral.

Dalam proses pemanfaatan elearning pada satuan pendidikan maka beberapa langkah dapat diambil antara lain Albab $(2020)$; 1) analisis kebutuhan dalam pembelajaran elearning dalam satuan pendidikan sehingga dapat diketahui kelemahan, kekuatan, peluang dan tantangan, 2) mengidentifikasi strategi dalam proses pembelajaran elearning, 3) pengembangan elearning, 4) menganalisis efektivitas dan efisiensi dalam e learning. Nurdiyansyah dan Eni menemukan keunggulan dalam pemanfaatan pembelajaran elearning antara lain Nurdiansyah and Fahyuni (2016)

1. Adanya fasilitas antara siswa dan guru melakukan komunikasi dengan mudah secara intensif tanpa dibatasi tempat, jarak dan waktu.

2. Penggunakan bahan ajar yang digunakan siswa dan guru secara terstruktur dan terjadwal sehingga dapat di evaluasi bersama.

3. Siswa dan guru dapat mengakses setiap saat dan kapan saja, dan bisa tersimpan secara digital di komputer.

4. Tambahan informasi yang berkaitan, dapat diakses di laman situs secara lebih mudah.

5. Diskusi interaktif antara pemberi dan penerima informasi dapat diikuti dengan jumlah peserta yang banyak.

6. Perubahan peran dan peserta didik dari pasif menjadi aktif dan mandiri.

7. Efisiensi waktu dan tempat, jangkauan tempat belajar dapat teratasi selama sinyal intenet mendukung.

Selain dengan kelebihan elearning dijabarkan, Nurdiyansyah dan Eni menemukan kekurangan dalam pemanfaatan pembelajaran elearning antara lain Nurdiansyah and Fahyuni (2016)

1. Interaksi guru dan siswa yang kurang terbentuk.

2. Interaksi siswa dengan teman sebaya kurang terjalin.

3. Cenderung mendorong pada aspek bisnis/komersial, kurang dalam aspek akademik atau sosial.

4. Proses pembelajaran lebih banyak dengan penerapan dan pelatihan, kurang pada konten pendidikan.

5. Perubahan peran guru sebagai pendidik.

6. Siswa yang tidak memiliki motivasi tinggi akan cenderung gagal dalam pembelajaran ini.

7. Ketersediaan internet dan akses alat penunjang misalnya komputer dan handphone.

8. Kurangnya ketrampilan dalam mengoperasikan internet.

9. Kurangnya sumber daya manusia yang ahli dalam bahasa pemrograman komputer.

\section{Sosiologi Pendidikan}

Sosiologi merupakan suatu ilmu yang mempelajari interaksi yang muncul pada suatu lembaga kemasyarakatan. Ilmu ini mempelajari tentang gejala yangada dan berjalan dalam suatu kelompok masyarakat. Sosiologi berhubungan dengan perubahan sosial yang terjadi di suatu masa. Konsep perubahan sosial menjadi dasar utama dalam interaksi sosial Gunawan (2000). Perubahan sosial memiliki unsur komponen kebudayaan secara immaterial maupun material dimana perubahan tersebut terjadi dalam struktur dan fungsi masyarakat sesuai dengan pendapat William F. Ogburn dan Meyer F Nimkoff dan dinyatakan ulang oleh Soerjono Soekanto Soekanto (1990). Dalam hal ini perubahan pada sistem pendidikan dan penyelenggaraan pendidikan yang terjadi pada era Pandemi Covid 19 merupakan keniscayaan bagi dunia pendidikan.

Gillin dan Gillin dalam Soerjono Soekanto menyatakan bahwa perubahan sosial memiliki variasi dalam melaksanakan cara hidup dan diterima di masyarakat. Variasi yang berpengaruh pada cara hidup masyarakat terjadi akibat komposisi dan jumlah penduduk, kebudayaan material, perbedaan geografis, ideologi maupun adanya penemuan baru yang berkembang pada suatu masyarakat. Samuel Koenig juga merujuk tentang berbagai modifikasi internal dan eksternal yang berkembang pada masyarakat Soekanto (1990). Perubahan sosial yang terjadi akan berpengaruh pada sistem sosial yang terbentuk, sikap individu, nilai-nilai, dan pola perilaku yang berjalan pada organisasi kemasyarakatan sebagai kelompok sosial manusia. Perubahan ini terjadi dipengaruhi oleh kondisi dan struktur masyarakat sesuai dengan pendapat Selo Soemardjan dan dikutip pada Soerjono Soekanto.

Perubahan sosial merupakan suatu gejala sosial yang terjadi sebagai ciri utama masyarakat mengikuti dinamika masyarakat yang terus menerus berubah. Seluruh masyarakat pasti mengalami perubahan sosial namun memiliki intensitas perubahan sosial yang berbeda beda. Frekwensi perubahan sosial dapat berjalan secara cepat (revolusi) ataupun secara lambat (evolusi) akan berjalan terus menerus Gunawan (2000). Spott mengurai adanya perubahan sosial yang terjadi dari luar (exogenous change) dan perubahan terpola (pattern change) Faisal (1987). Secara sifatnya, perubahan terjadi direncanakan maupun tidak terencana. Perubahan yang direncanakan merupakan perubahan yang dikehendaki oleh pihak pihak tertentu (agent of change). Perubahan ini dapat berupa perubahan yang ditentukan dari atas (top-down) dan dari bawah (bottom-up). Perubahan yang tidak terencana merupakan perubahan yang tidak diinginkan dan cenderung mendapatkan pertentangan dan penolakan yang merugikan.

Terdapat tiga dimensi perubahan sosial yaitu dimensi struktural, kultural dan interaksional sesuai dengan teori Himer dan More dalam Soelaiman (1998). Dimensi struktural merupakan perubahan bentuk struktur masyarakat, perubahan peran masyarakat, perubahan struktur kelas sosial dan lembaga sosial. Dimensi kultural memiliki perubahan kebudayan pada masyarakat, perubahan akibat hasil teknologi, kontak dengan kebudayaan lain dan menyebabkan adanya difusi 
kebudayaan. Perubahan yang berhubungan dengan frekuensi, jarak sosial, saluran, aturan dan pola serta adanya bentuk hubungan baru akan menjadi acuan dalam dimensi interaksional. Pendidikan merupakan suatu wadah yang efektif dalam proses perubahan sosial. Dalam hal ini pendidikan menjadi agen perubahan sosial (agent of changes) yang terjadi pada masyarakat. Pendidikan memberikan pengaruh dalam perubahan sosial. Interaksi timbal balik ini menjadi fungsi sosiologik dalam pendidikan Rijono (2003).

Sosiologi pendidikan merupakan cabang sosiologi yang memiliki fokus mempelajari struktur dan organisasi pendidikan dan interaksi sosial yang berjalan dalam suatu sistem dan institusi pendidikan. Pendidikan sebagai suatu fakta sosial dikemukakan Durkheim dan bersifat empiris. Fokus kajian pada fakta sosial ini terdiri dari struktur sosial (social structure) dan pranata sosial (social institution). Kedua definisi tersebut membantu tindakan manusia penuh arti (makna) Anshori (2018). Sosiologi pendidikan memiliki ruang lingkup dan bertujuan untuk memecahkan problematika yang dialami di dunia pendidikan. Hal ini mencakup interaksi sosial peserta didik dengan guru, teman sesama dan lingkungan. Selain itu sosiologi pendidikan mengamati gejala gejala sosial yang berkembang pada sistem pendidikan dan aspek aspek sosial yang berkembang dalam dunia pendidikan. Hal ini dilakukan untuk mencapai pendidikan yang konstruktif Noho and Ohoitenan (2019). Sosiologi pendidikan melakukan analisa pola interaksi antara institusi pendidikan yaitu sekolah dengan kelompok sosial di masyarakat Adiwikarta (1988). Beberapa analisa yang dapat dilakukan antara lain 1) struktur kekuasaan di masyarakat dan hubungannya dengan institusi pendidikan, 2) hubungan antara institusi pendidikan dengan sistem sosial lainnya, 3) struktur masyarakat dan pengaruhnya terhadap organisasi sekolah.

Sosiologi pendidikan dalam hubungannya memiliki tiga arah yaitu secara makro, meso dan mikro Noho and Ohoitenan (2019). Sosiologi pendidikan makro mengamati hubungan antara pendidikan dan institusi lain dalam masyarakat, misalnya hubungan pendidikan dengan agama, hubungan pendidikan dengan politik dan hubungan pendidikan dengan ekonomi. Sosiologi pendidikan meso mengamati hubungan yang terjadi dalam organisasi/lembaga pendidikan dan interaksi yang terjadi dan aturan yang diterapkan lembaga pendidikan agar mampu mencapai tujuan pendidikan dalam hal ini misalnya struktur organisasi, peran dan fungsi struktur organisai, hubungan sekolah dengan organisasi masyarakat yang terbentuk. Sosiologi pendidikan mikro yakni membahas interaksi sosial yang berlangsung dalam institusi pendidikan, kelompok yang terbentuk di kalangan siswa, interaksi dalam kelas, interaksi siswa dengan guru, strategi organisasi pembelajaran, strategi penyampaian pembelajaran dan strategi pengelolaan pembelajaran. Dalam perkembangannya, pendidikan saat ini memiliki lima fungsi dan dan arah Tilaar (2000) antara lain:

1. Fungsionalisme; fungsi pendidikan sebaga upaya mentrans- misikan kebudayaan dan mempertahankan tatanan sosial yang telah berjalan. Peserta didik diberikan fungsi fungsi dalam masyarakat masa depan. Durkheim dan Parsons merupakan tokoh dalam aliran ini.

2. Kulturalisme; pendidikan sebaga upaya melakukan rekonstruksi pemikiran masyarakat dan membentuk tatanan masyarakat dengan dasar budaya universal dengan modal budaya lokal yang berkembang ke arah budaya nasional dan kebudayaan global. Brameld dan Ki Hajar Dewantara merupakan tokoh yang berperan dalam aliran ini.

3. Kritikal; terdapat 2 aliran dalam fungsi ini yaitu aliran teori konflik dan teori kritikal. Bagi penganut aliran teori konflik fungsi pendidikan berperan sebagai pembentuk tatanan ekonomi menuju pada pemerataan ekonomi dengan perjuangan kelas pada masyarakat yang berkembang. Bowels dan Karl Marx merupakan tokoh yang berperan. Penganut teori kritikal memfungsikan pendidikan sebagai usaha pemberdayaan kaum tertindas. Usahanya adalah dengan pengembangan keaksaraan kritikal bagi masyarakat. Freire, Gyroux dan Vyotzky merupakan tokoh yang berperan dalam aliran ini.

4. Interpretatif ; fungsi pendidikan adalah mengurangi bias budaya dan kelas sosial yang terbentuk dari perbedaan ekonomi menjadi kelompok elite dengan rakyat miskin. Pendidikan dilaksanakan untuk memahami peran peran dalam masyarakat melalui berbagai program kurikulum yang dibentuk. Bersntein merupakan tokoh dalam aliran ini.

Pascamodern; fungsi pendidikan dilakukan sebagai pembinaan atas pribadi bebas dalam merumuskan pendapat dan mampu menyatakan pendapat sendiri dalam berbagai perspektif. Derrida, Foucoult dan Gramsei merupakan tokoh dalam aliran ini. Tilaar mengutip pernyataan Ackerman dan Alscot bahwa masyarakat saat ini sangat sadar dengan kebutuhan dan pencapaian keingiannya. Masyarakat memiliki hak dalam mencapai tujuannya. Oleh sebab itu maka lembaga pendidikan harus menyediakan keinginan masyarakat, tidak hanya kebutuhan birokrasi saja. Akibatnya proses pendidikan ditentukan oleh para stakeholders yaitu masyarakat, orang tua, peserta didik, negara dan pengelola profesional pendidikan. Partisipasi masyarakat ini dapat berupa investasi SPP, pajak dan juga turut serta dalam perencanaan kurikulum pendidikan, evaluasi pendidikan dan proses pembelajaran. Wadah masyarakat ini dilaksanakan melalui manajemen pendidikan berbasis sekolah dan manajemen pendidikan berbasis masyarakat Tilaar (2000). Paradigma baru ini telah dikembangkan di era Indonesia dewasa ini.

Perubahan sosial dalam masyarakat dipengaruhi oleh beberapa faktor; perubahan kondisi geografis, kebudayaan material, komposisi penduduk, ideologi maupun difusi dan penemuan baru yang mempengaruhi kehidupan masyarakat secara internal maupun eksternal. Dalam pembahasan sosiologi pendidikan fungsi pendidikan adalah proses memanusiakan manusia secara manusiawi yang harus disesuaikan den- 
gan situasi, kondisi dan perkembangan zaman. Pendidikan merupakan proses yang dapat terjadi di mana pun, kapan pun dan siapa pun. Oleh sebab itu setiap individu harus bisa menguasai ketrampilan yang bermanfaat untuk merespon kebutuhan hidupnya Zainuddin (2008).

\section{Interaksi Pada Manusia}

Interaksi sosial merupakan syarat utama terjadinya aktivitas dan integrasi sosial. Interaksi sosial adalah hubungan sosial yang dinamis dan melakukan koneksi orang per orang, antara kelompok-kelompok manusia, maupun antara orang per orang dengan kelompok manusia sesuai dengan Kymlicka dalam Lestari. Interaksi seseorang maupun kelompok sosial merupakan proses usaha dan belajar untuk memahami tindakan sosial seorang individu ataupun kelompok sosial lain Lestari (2013). Interaksi sosial terjadi secara tertib dan teratur jika seseorang dapat berperilaku sesuai dengan konteks sosialnya, yakni tindakan yang disesuaikan dengan situasi sosial saat itu, berperilaku pada norma-norma yang berlaku, dan bertindak berdasarkan posisinya dalam masyarakat. Suatu interaksi sosial dapat berjalan dengan lancar jika memenuhi dua syarat yaitu adanya kontak sosial dan komunikasi Lestari (2013). Kontak dan komunikasi akan mewujudkan interaksi sosial sehingga mampu melaksanakan peran dalam kehidupannya.

Faktor-faktor yang mempengaruhi interaksi sosial menurut Santoso adalah situasi sosial, kekuasaan norma kelompok, tujuan pribadi masing-masing individu, interaksi sesuai dengan kedudukan dan kondisi setiap individu serta penafsiran situasi. Tanpa faktor-faktor tersebut niscaya interaksi tidak dapat terjadi Lestari (2013). Interaksi sosial adalah kunci dari semua kehidupan sosial oleh karena itu tanpa adanya interaksi sosial tidak akan mungkin ada kehidupan bersama. Interaksi sosial dimaksudkan sebagai pengaruh timbal balik antar individu dengan golongan di dalam usaha individu untuk memecahkan persoalan yang diharapkan dan dalam usaha untuk mencapai tujuannya Ahmadi (2009) .

Interaksi sosial merupakan aspek dinamis dari masyarakat. Interaksi ini merupakan proses koneksi antara individu satu dengan individu lain. Koneksi ini terjadi karena manusia sebagai makhluk sosial. Maka secara naluri akan melakukan hubungan dengan individu lain guna memenuhi kebutuhan hidupnya Lestari (2013). Soekanto dalam Effendi menyatakan hubungan sosial (sosialisasi) adalah hubungan antarmanusia (interaksi sosial) yang saling membutuhkan untuk mencukupi kebutuhannya. Interaksi sosial dapat membentuk hubungan sosial dinamis.Sosialisasi memiliki tingkatan dari sederhana dan terbatas hingga kompleks. Interaksi ini mengkaitkan hubungan antara orang-orang perorangan, antara kelompokkelompok manusia, maupun antara orang perorangan dengan kelompok manusia. Beberapa elemen yang berpengaruh dalam keberlangsungan interaksi sosial tunggal maupun bersamaan adalah imitasi, sugesti, identifikasi, dan simpati Efendi et al. (2017). Interaksi sosial memiliki dua kategori, yaitu yang bersifat asosiatif (gabungan) dan disosiatif (pertolakbelakan- gan) Efendi et al. (2017) antara lain;

1. Interaksi sosial yang bersifat asosiatif. Interaksi antar individu yang bertujuan pada bentuk bentuk hubungan atau gabungan. Beberapa contohnya seperti; a) akomodasi, yaitu proses interaksi sosial antara individu dan himpunanhimpunan manusia yang bertujuan untuk meredakan ketegangan dan pertentangan; b) kerja sama, yaitu suatu interaksi sosial yang bertujuan untuk mendapatkan hasil bersama dengan cara usaha bersama; c) akulturasi, yaitu suatu usaha sosial dimana suatu kelompok masyarakat manusia dengan suatu kebudayaan tertentu mendapatkan unsur dari suatu kebudayaan asing (luar). Sejalan dengan waktu, unsur kebudayaan tersebut diterima, diolah, dan diadaptasi, melebur ke dalam kebudayaan sendiri. Namun, cenderung menghilangkan kepribadian pada kebudayaan awal; d) asimilasi, yaitu usaha sosial terjadi apabila kelompok masyarakat yang mempunyai perbedaan latar belakang, melakukan interaksi kontinu, berlangsung lama yang berakibat pada perubahan sifat kebudayaan asli, terbentuk kebudayaan baru dengan berbagai macam campuran kebudayaan.

2. Interaksi sosial yang bersifat disosiatif meliputi: a) Persaingan, yaitu suatu interaksi sosial secara individu maupun himpunan masyarakat untuk mendapatkan kemenangan atau hasil. Interaksi yang muncul bersifat kompetisi, namun tanpa menghasilkan ancaman atau benturan fisik di pihak lawannya; b) Konflik adalah suatu interaksi sosial secara individu maupun himpunan masyarakat karena perbedaan paham dan kepentingan sehingga menimbulkan gesekan sosial yang sangat mendasar; c) Kontravensi adalah bentuk proses sosial yang berada di antara persaingan dan pertentangan atau konflik.

Pandemi COVID 19 ini membutuhkan peran penting akan teknologi informasi dan komunikasi. Khususnya dunia pendidikan. Keberadaan teknologi informasi dan komunikasi mendorong lembaga pendidikan dapat memberdayakan sumber daya manusia ke arah pembelajaran digital. Hal ini dilakukan agar dapat menjawab tantangan akibat perubahan global yang bersifat dinamis.

Pemerintah Indonesia mendorong agar seluruh lembaga pendidikan untuk melalukan pembelajaran elearning agar dapat menghentikan penyebaran virus tersebut. Keberadaan e-learning adalah alternatif agar proses kegiatan belajar dan mengajar tetap terlaksanakan. Peralihan dari proses pendidikan tatap muka menjadi daring (Online) atau e-learning dikategorikan sebagai disrupsi pendidikan. Namun belum ada model pembelajaran lain yang efisien dan efektif dan bisa diterapkan di masa pandemi ini selain elearning. Dengan adanya akses internet, maka pembelajaran tidak dilakukan dengan tatap muka secara langsung. Hal ini dilakukan karena untuk menjaga agar mobilitas individu. Pembelajaran model ini dapat dilakukan dimana saja dan kapan saja dengan syarat alat yang digunakan dalam proses pembelajaran ini mendukung dan terhubung dengan internet. Kelebihan dalam pembela- 
jaran elearning ternyata banyak juga kendala-kendala yang dialami oleh siswa maupun guru dalam proses pengaksesan. Selain itu terdapat beberapa kendala-kendala yang dialami oleh guru dan peserta didik dalam pembelajaran elearning. Harus diakui bahwa pembelajaran elearning menajadi salah satu alternatif pembelajaran yang dilakukan dengan keadaan yang tidak memungkinkan, seperti halnya kasus Pandemi Covid-19.

Pertama, lembaga pendidikan Islam dalam menghadapi sistem pembelajaran berbasis online atau elearning yang beragam. Kondisi ini memaksa lembaga pendidikan Islam mengerahkan segala sumber daya untuk bisa bertahan dengan tujuan pendidikan. Mau atau tidak mau, suka atau tidak suka lembaga tersebut harus mengimplementasikan sistem pembelajaran berbasis elearning ketika mengalami situasi dan kondisi seperti saat ini. Lembaga pendidikan Islam yang telah menyiapkan diri akan terus mengasah kemampuan menjadi lebih baik. Namun bagi lembaga yang belum menyiapkan diri, akan kesulitan untuk bisa beradaptasi. Hal ini karena sudah menjadi kesepakatan, kesadaran bersama dan bersifat tuntutan zaman. Namun dengan adanya kluster pendidikan, koneksi antar lembaga, pertukaran informasi yang sangat cepat, maka proses ini akan bisa dilalui, cepat atau lambat.

Kedua, tentang koneksi dan jaringan. Setiap lembaga memiliki peserta didik dari berbagai daerah. Hal ini menyebabkan kendala terkait kendala dengan pembelajaran online yaitu koneksi internet. Setiap peserta didik menggunakan provider perdana atau koneksi internet yang berbeda. Hal ini menyebabkan informasi yang diberikan memiliki kecepatan yang berbeda. Peserta didik yang memiliki koneksi cepat akan menerima informasi lebih dahulu. Begitu juga sebaliknya.

Ketiga, Paket Internet atau Kuota. Peserta didik harus memiliki sumber daya untuk menyediakan paket kuota. Bagi Peserta didik yang berkemampuan, bukanlah hal yang sulit. Namun hal tersebut menjadi kendala bagi peserta didik yang tidak mampu menyediakannya dalam proses pembelajaran online. Masalah ini terjadi pada sebagian keluarga peserta didik dari golongan menengah kebawah dan ekonomi rendah. Jadi paket kuota merupakan kendala yang dihadapi oleh sebagian peserta didik dalam proses pembelajaran online (elearning).

Keempat, gawai (gadget) yang tidak memadai. Terdapat faktor lain yang menjadi kendala proses pembelajaran online, yaitu gawai (gadget) yang tidak memadai dan tidak mendukung koneksi internet. Perangkat yang tidak memadai bisa menjadi penghambat. Misalnya laptop/komputer dengan perangkat Wi-Finya yang rusak, Smartphone yang tergolong jadul, mungkin sudah berbasis android, namun spesifikasi dan operational system (OS) gawai yang lama terkadang mempengaruhi koneksi internet. Operational system yang lama akan mempengaruhi kecepatan gawai membuka laman elearning, terkadang juga sering error dan laman tidak kompatibel dengan sistem operasi yang lama.

Kelima, tingkat pemahaman materi. Pada pembelajaran online peserta didik disajikan materi pembelajaran dan men- jawab pertanyaan-pertanyaan sebagai evaluasi. Akan tetapi terdapat sebagian peserta didik mengeluhkan pemahaman yang sering kali belum dimengerti. Karena peserta didik tersebut berasumsi bahwa pengajaran guru lebih mudah dipahami dari pada membacanya sendiri. Terdapat dua kemungkinan yang menjadi sebab permasalahan. Pertama, karena materi yang berantakan, maka kendala ini dari segi teksnis. Kedua, karena peserta didik sulit memahami materi yang telah dipaparkan, maka hal tersebut menunjukan bahwa terdapat materi yang memang harus dipraktikkan secara langsung dan dengan tatap muka.

Keenam, kendala materi. Kendala ini dijumpai oleh guru pembuat soal, khususnya soal-soal yang berkaitan dengan rumus-rumus. Soal atau materi menjadi berantakan ketika sudah dipaparkan di website e-learning. Dari segi peserta didik, jika materi berantakan di layar, otomatis informasi yang didapat peserta didik juga berantakan.

Hambatan-hambatan teknologi ini terjadi dan berimbas pada penurunan motivasi dan semangat untuk belajar. Jika kondisi motivasi peserta didik sudah menurun maka peserta didik sudah malas untuk mengerjakan dengan sungguhsungguh. Akibatnya pembelajaran dilakukan sebagai usahapartisipasi dan kehadiran peserta didik saja.Peran pendidikan yang menunjukkan manusia dari masa kebodohan menjadi masa menjadi mengerti sangatlah penting. Karena manusia juga harus menyadari bahwa zaman akan terus berkembang. Dunia pendidikan mengalami perkembangan akibat tuntutan zaman sehingga melakukan peralihan dari pendidikan tatap muka menjadi pendidikan daring. Namun, hal tersebut tidak terlepas dari berbagai kendala, mulai dari kendala koneksi internet hingga kendala pemahaman peserta didik jika pembelajarannya dalam bentuk teks.

Pendidikan Islam merupakan wadah untuk membentuk intelektualisme dan nilai yang muncul pada individu sehingga mampu mempengaruhi perubahan sosial islami masyarakat secara kontinu dan masif. Peranan ini berdasarkan nilai atau akhlak dalam konteks intelektualitas maupun internalisasi nilai yang dikembangkan di masyarakat. Nilai nilai islami yang di kembangkan di sekolah merupakan nilai nilai yang akan berkembang di masyarakat. Lembaga Pendidikan Islam menjadi bagian untuk menjaga keberlangsungan nilai Islami di sebuah komunitas. Kondisi pandemi juga menyebabkan keterbatasan interaksi secara fisik. Interaksi sosial akan terjadi apabila tercukupi dua syarat yaitu adanya kontak sosial dan komunikasi. Dua hal ini menghasilkan sebuah interaksi sosial sehingga mampu melaksanakan peran dalam kehidupannya. Dalam prinsip pembatasan mobilitas (karantina), komunikasi dapat terjalin dengan adanya pemanfaatan teknologi informasi dan elearning. Namun kontak sosial secara fisik sangat lemah karena tidak adanya pertemuan dan kurangnya interaksi. Faktor-faktor yang mempengaruhi interaksi sosial pada pembelajaran elearning adalah antara lain:

1. situasi sosial; dimana kondisi pandemi memaksa peserta didik dan guru serta manajemen untuk mengurangi tatap 
muka. Sehingga situasi ini memaksa keterbatasan interaksi. Situasi ini memang tidak bisa dirubah. Namun individu harus bisa beradaptasi dalam usaha bertahan hidup. Sejatinya manusia memiliki naluri untuk bertahan hidup. Sehingga mau tidak mau, suka tidak suka, individu akan mengurangi interaksi fisik. Begitu juga dunia pendidikan mengambil langkah terbaik untuk menjaga kesehatan dan kestabilan sosial.

2. Tujuan pribadi guru-siswa, siswa-siswa dan siswalingkungan, interaksi fisik dan kondisi setiap individu serta penafsiran situasi.

Dalam pelaksanaan pembelajaran elearning interaksi yang kemungkinan muncul adalah sebagai berikut;

1. Discovery (menemukan) hal hal yang baru, meliputi browsing dan pencarian informasi tertentu yang berkaitan dan berhubungan dengan materi yang diingini. Peserta didik akan menggali informasi sebanyak yang ia inginkan untuk dapat memahami materi pembelajaran. Peserta didik yang bermotivasi tinggi menemukan hal hal baru akan mendapatkan informasi lebih banyak. Begitu juga sebaliknya.

2. Communication (komunikasi) jaringan internet memberikan informasi secara cepat, murah dan kompleks antar dan inter lembaga. Peserta didik dapat mencari informasi lebih cepat dari teman sebaya, dari aplikasi pencarian dan dari individu lain. intensitas komunikasi ini terjadi di dunia maya. Hal ini ibarat pisau bermata dua. Di satu sisi komunikasi bisa lebih intens dan tak terbatas waktu. Namun di sisi lain norma, sopan santun, adab, akhlak tidak bisa tersirat dengan kata kata dalam bentuk teks. Proses ini akan menimbulkan persepsi yang berbeda dari pemberi kepada penerima pesan. Inilah yang disebut dalam hambatan komunikasi pada organisasi. Hal ini juga terjadi di dunia pendidikan.

3. Collaboration, (kolaborasi) menggabungkan beberapa informasi yang berkaitan dengan informasi lainnya yang diinginkan oleh pengguna. Interaksi ini bersifat asosiatif. Artinya hubungan siswa dan lingkungan pendidikan bersifat gabungan dan terkait erat. Namun terdapat hubungan disosiatif yaitu konflik yang muncul dari luar, misalnya dari perbedaan pemahaman dan kepentingan terhadap Pandemi COVID 19.

\section{Pembahasan}

Pandemi ini merupakan fenomena yang tidak dapat dihindari. Oleh sebab itu berbagai usaha dilakukan untuk membatasi mobilitas individu yang mengarah pada perubahan di berbagai bidang terutama bidang pendidikan Islam. Perubahan ini dilakukan sebagai salah satu bentuk adaptasi untuk bisa bertahan dari tantangan ini. Inovasi pendidikan dilaksanakan untuk tetap mempertahankan interaksi yang muncul, yaitu kegiatan belajar mengajar. Salah satu strategi yang dilakukan adalah melaksanakan inovasi proses pembelajaran. Hal ini bertujuan agar bahan ajar bisa tersampaikan pada peserta didik secara efektif dan efisen. Akibat kondisi ini terjadi perubahan pola pendidikan dalam jaringan (daring) selama masa di rumah. Lembaga pendidikan berperan menjaga nilai moral yang diajarkan dan menjadi dasar pertumbuhan masyarakat. Fungsi pendidikan ini dilaksanakan dari rumah. Proses pembelajaran harus dilaksanakan dengan alternatif pemanfaatan teknologi berbasis informasi dan komunikasi sebagai usaha peningkatan kualitas pendidikan. Penerapan model pembelajaran Elearning bisa dilakukan dengan keterbatasan mobilitas. Model pembelajaran ini akan mendorong efektivitas dan fleksibilitas pendidikan. Pembelajaran ini mampu memfasilitasi siswa melakukan discovery (menemukan) hal hal yang baru, communication (komunikasi) informasi secara cepat, murah dan kompleks antar dan inter lembaga, collaboration (kolaborasi) beberapa informasi yang berkaitan untuk mendapatkan gambaran utuh suatu materi.

Perubahan sosial islami yang terjadi berpengaruh pada sistem sosial, sikap, nilai-nilai sosial dan perilaku pada kelompok manusia. Perubahan ini dipengaruhi oleh kondisi dan pergeseran struktur masyarakat akibat pandemi ini. Kondisi pandemi menyebabkan adanya perubahan sosial yang terjadi dari luar (exogenous change). Perubahan ini terjadi tidak direncanakan dan mendapatkan pertentangan dan penolakan yang merugikan. Pertentangan dan penolakan interaksi sosial siswa terhadap guru, teman sesama dan lingkungan terjadi pada saat proses pembelajaran. Interaksi ini merupakan salah satu aktivitas dan integrasi sosial. Kondisi pandemi juga menyebabkan keterbatasan interaksi secara fisik. sedangkan interaksi sosial terjadi jika terjadi dua syarat yaitu terjadi kontak sosial dan komunikasi. Kontak dan komunikasi akan mewujudkan interaksi sosial sehingga mampu melaksanakan peran dalam kehidupannya. Oleh sebab itu maka Lembaga Pendidikan Islam dan guru guru harus senantiasa memberikan informasi dan perkembagan terkait pendidikan islami yang diajarkan. Informasi ini harus berjalan secara reguler dan kontinu. Semakin tinggi intensitas penemuan (discovery), komunikasi dan kolaborasi pada siswa, guru dan lembaga pendidikan Islam, maka semakin kuat kontak yang terbentuk. Peningkatan kontak ini akan memperkuat interaksi yang terjadi. Sehingga dengan adanya kelancaran arus informasi maka mempercepat terjadinya perpindahan nilai nilai Islami (transfer of Values).

Dalam prinsip pembatasan mobilitas, komunikasi dapat terjalin dengan adanya teknologi informasi dan elearning. Namun kontak sosial sangat lemah karena tidak adanya pertemuan dan kurangnya interaksi. Hal ini terjadi karena faktor faktor sosial yang muncul akibat pandemi ini. Interaksi ini bersifat asosiatif. Artinya dalam hubungan siswa dan lingkungan pendidikan islam bersifat gabungan dan berhubungan erat. Namun terdapat hubungan disosiatif yaitu konflik yang muncul dari luar, misalnya dari perbedaan pemahaman dan kepentingan terhadap Pandemi COVID 19. 


\section{KESIMPULAN}

Pandemi COVID 19 memaksa dunia pendidikan melakukan inovasi pendidikan yang dibuat sebagai langkah untuk bisa tetap bertahan dengan interaksi ranah pendidikan. Inovasi proses pembelajaran merupakan strategi penting dalam inovasi sekolah. Pemanfaatan TIK dilakukan sebagai salah satu usaha dalam meningkatkan usaha menjalankan pendidikan. Elearning merupakan model pembelajaran yang bisa diterapkan dengan keterbatasan mobilitas. Namun elearning adalah alat seperti pisau bermata dua. Di satu sisi metode ini memiliki efektivitas yang dapat berjalan di masa pandemi. Namun di sisi lain terdapat perubahan sosial yang terjadi. Perubahan sosial ini merubah transisi pengetahuan, sikap, kepercayaan,

\section{REFERENCES}

Abidah, A., Hidaayatullaah, H. N., Simamora, R. M., Fehabutar, D., and Mutakinati, L. (2020). The Impact of Covid-19 to Indonesian Education and Its Relation to the Philosophy of "Merdeka Belajar". Studies in Philosophy of Science and Education 1, 38-49. doi: 10.46627/sipose.v1i1.9.

Abodunrin, O., Oloye, G., and Adesola, B. (2020). Coronavirus Pandemic and its Implication on Global Economy. International Journal of Arts, Languages and Business Studies (IJALBS) 4, 13-23.

Adiwikarta, S. (1988). Sosiologi Pendidikan, Isyu dan Hipotesis tentang Hubungan Pendidikan dengan Masyarakat (Jakarta: Proyek Pengembangan Lembaga Pendidikan Tenaga Kependidikan).

Ahmadi, A. (2009). Psikologi Sosial (Jakarta: Rineka Cipta).

Albab, S. U. (2020). Analisis Kendala Pembelajaran E-Learning Pada Era Disrupsi Di SMK Terpadu Al-Islahiyah Singosari Malang. Mudir: Jurnal Manajemen Pendidikan 2, 46-57.

Anshori, I. (1993). Dilema Tanggung Jawab Guru Masa Depan (Menjangkau Garis Awal "Era Baru” 1993) 76, 51-52.

Anshori, I. (2004). Standar Kualitas Guru Di Masa Depan. KHAZANAH.

Anshori, I. (2018). Melacak State Of The Art Fenomenologi Dalam Kajian IlmuIlmu Sosial. Halaqa: ISlamic Education Journal 2, 165-181.

Currie, G., Macleod, M., Sena, E., Bahor, Z., Liao, J., Sena, C., et al. (2020). Protocol for a "Living" Evidence Summary of Primary Research. OSF HOME.

dan Kebudayaan (Kemendikbud)), K. P. (2020). Surat Edaran Nomor 4 Tahun 2020 Tentang Pelaksanaan Kebijakan Pendidikan Dalam Masa Darurat Penyebaran Coronavirus Disease (COVID 19).

Efendi, A., Astuti, P. I., and Rahayu, N. T. (2017). Analisis Pengaruh Penggunaan Media Baru Terhadap Pola Interaksi Sosial Anak Di Kabupaten Sukoharjo. Jurnal Penelitian Humaniora 18, 12-24. doi: 10.23917/humaniora.v18i2.5188.

Faisal, S. (1987). Sosiologi Pendidikan (Surabaya: Usaha Nasional).

Gunawan, A. H. (2000). Sosiologi Pendidikan Suatu Analisis Sosiologi Tentang Pelbagai Problem Pendidikan (Jakarta: Rineka Cipta).

Hartanto, A. A. and Purbo, O. W. (2002). Teknologi e-Learning (Jakarta: Elex Media Komputindo).

Lahmi, A. (2016). Peranan Sekolah Dalam Pendidikan Islam. Istawa: Jurnal Pendidikan Islam 1, 120-120. doi: 10.24269/ijpi.v1i2.172.

Lai, C.-C., Shih, T.-P., Ko, W.-C., Tang, H.-J., and Hsueh, P.-R. (2020). Severe acute respiratory syndrome coronavirus 2 (SARS-CoV-2) and coronavirus disease2019 (COVID-19): The epidemic and the challenges. International Journal of Antimicrobial Agents 55, 105924-105924. doi: 10.1016/j.ijantimicag.2020. 105924.

Lestari, I. P. (2013). Interaksi Sosial Komunitas Samin Dengan Masyarakat Sekitar. Komunitas: International Journal of Indonesian Society and Culture 5, 74-86. doi: https://doi.org/10.15294/komunitas.v5i1.2376.

Mahase, E. (2020). China coronavirus: what do we know so far? BMJ 1, 1-2. doi: 10.1136/bmj.m308.

Maliki, Z. (2010). Sosiologi Pendidikan (Universitas Gajah Mada: Gajah Mada University Press). ketrampilan dan aspek aspek lain. Akibatnya perubahan sosial dalam pendidikan sebagai proses mengajar dan belajar akan mengalami pergeseran sosial.

\section{UCAPAN TERIMA KASIH}

Terima kasih kami berikan kepada beberapa dosen pengasuh diantaranya adalah Dr. Istikomah, M.Ag, Dr. Eny Fariyatul Fahyuni, Dr. Isa Anshori, M.Si, Ucapan terima kasih juga saya ucapkan kepada SMA Muhammadiyah 2 Sidoarjo sebagai lembaga tempat saya melakukan penelitian dan semua personal didalamnya yang membantu hingga penulisan artikel ini selesai. Serta tidak lupa teman teman seangkatan program Pasca Sarjana yang tidak dapat saya sebutkan satu persatu.
Muhtadi, A. (2006). Pemanfaatan Teknologi Informasi Untuk Meningkatkan Kualitas Dan Efektifitas Pendidikan. Dinamika Pendidikan 13, 1-10.

Noho, M. and Ohoitenan, I. I. (2019). Konsep Sosiologi Pendidikan (Analisis Makro , Meso dan Mikro Sosiologi Pendidikan ). Jurnal Kajian Pendidikan Keislaman $11,65-79$.

Nurdiansyah and Fahyuni, E. F. (2016). Inovasi Model Pembelajaran Sesuai Kurikulum 2013 (Univeritas Muhammdiyah Sidoarjo: Nizamia Learning Center).

Nurkolis, N. and Muhdi, M. (2020). Keefektivan Kebijakan E-Learning berbasis Sosial Media pada PAUD di Masa Pandemi Covid-19. Jurnal Obsesi : Jurnal Pendidikan Anak Usia Dini 5, 212-212. doi: 10.31004/obsesi.v5i1.535.

Organization, W. H. (2020). Coronavirus disease (COVID-19) pandemic. https://www.who.int/emergencies/diseases/novel-coronavirus-2019?gclid= Cj0KCQiAnb79BRDgARIsAOVbhRokwD53O1RWX8NfGOHaaWCIePb8dVqsSQ6eil68sEf wcB. (Accessed on 2020).

Rijono, N. (2003). Partisipasi Masyarakat Dalam Pendidikan; Kajian Fenomenologis Makna Partisipasi Bagi Masyarakat Etnis Kutai di Kecamatan Tenggarong Kabupaten Kutai Kartanegara (Malang: Universitas Merdeka).

Sarwono, S. W. (2011). Psikologi Remaja (Jakarta: Rajawali Press)

Soekanto (1990). Sosiologi Suatu Pengantar (Jakarta: Rajawali Press).

Soelaiman, M. M. (1998). Dinamika Masyarakat Transisi : Mencari Alternatif Teori Sosiologi Dan Arah Perobahan (Yogyakarta: Pustaka Pelajar).

Sudrajat, T., Komarudin, O., Ni'mawati, and Zaqiah, Q. Y. (2020). Inovasi Kurikulum dan Pembelajaran Pada Masa Pandemi Civid-19. Jurnal Ilmiah Wahana Pendidikan 6, 317-322. doi: https://doi.org/10.5281/zenodo.3960178.

Sugiyono (2017). MetodePenelitian Kuantitatif, Kualitatif dan R\&D (Bandung: PT Alfabeta).

Syafe'i, I. (2016). Model Pembelajaran Bahasa Arab Berbasis Kon- Struktivisme Di Perguruan Tinggi Islam. vol. 27, In Jurnal Pendidikan Islam, ed. A.-T. J. P. Islam (Sunan Gunung Djati State Islamic University of Bandung), 463-463. doi: 10.15575/jpi.v27i3.530.

Tilaar, H. A. R. (2000). Paradigma Baru Pendidikan Nasional (Jakarta: Rineka Cipta).

Triandoyo, M. and Anshori, I. (2020). Implementasi Sistem Informasi Pendidikan Muhammadiyah (Sidikmu) Dalam Layanan Administrasi Sistem Pe Nilaian Al Islam, Kemuhammadiyahan Dan Bahasa Arab (Ismuba) Pada Era Industri 4.0 Di Sekolah Dasar Muhammadiyah 1 Krian, Sidoarjo. International Journal on Integrated Education 3, 70-76. doi: 10.31149/ijie.v3i9.591.

Wajdi, M. B. N., Kuswandi, I., Faruq, U. A., Zulhijra, Z., Khairudin, K., and Khoiriyah, K. (2020). Education Policy Overcome Coronavirus, A Study of Indonesians. EDUTEC : Journal of Education And Technology 3, 96-106. doi: 10.29062/edu.v3i2.42.

WHO and Johnson, M. (2020). Wuhan 2019 Novel Coronavirus - 2019-nCoV. WHO International: The World Of The Laboratories 10. doi: doi.org/10.13070/ mm.en.10.2867.

Wimalawansa, S. J. (2020). Global Epidemic of Coronavirus - Covid-19: What Can We Do to Minimize Risks. European Journal Of Biomedical And Pharmaceutical Sciences 7, 432-438.

Zainuddin, M. (2008). Perubahan Sosial Dalam Perspektif Sosiologi Pendidikan. Jurnal Sosio-Religia 7, 752-760. 
Conflict of Interest Statement: The authors declare that the research was conducted in the absence of any commercial or financial relationships that could be construed as a potential conflict of interest.

Copyright (c) 2021 Mumthaza, Anshori and Istikomah. This is an open-access article distributed under the terms of the Creative Commons Attribution License (CC BY) The use, distribution or reproduction in other forums is permitted, provided the original author(s) and the copyright owner(s) are credited and that the original publication in this journal is cited, in accordance with accepted academic practice. No use, distribution or reproduction is permitted which does not comply with these terms. 